Pak. J. Anal. Environ. Chem. Vol. 19, No. 2 (2018) 135 - 145

\title{
Treatment of Municipal Wastewater Through Horizontal Flow Constructed Wetland
}

\author{
Ghulamullah Maitlo ${ }^{1 *}$ Ghulam Abbas Kandhro ${ }^{2}$, Abdul Karim Shah ${ }^{1}$, \\ Abdul Sattar Jatoi ${ }^{1}$ and Abdul Qayoom Memon ${ }^{1}$ \\ ${ }^{1}$ Department of Chemical Engineering, Dawood University of Engineering and Technology, Karachi, Sindh, \\ Pakistan. \\ ${ }^{2}$ Department of Basic Sciences, Mathematics and Humanities, Dawood University of Engineering and Technology, \\ Karachi, Sindh, Pakistan. \\ *Corresponding Author Email: metlo2696@yahoo.com \\ Received 16 April 2018, Revised 22 November 2018, Accepted 25 November 2018
}

\begin{abstract}
Highly contaminated municipal wastewater is being disposed of into land and rivers without any prior treatment has severe side effects on human and marine animals. This research focused on the treatment of Majeed Keerio village municipal wastewater through horizontal flow constructed wetland system. The experimental study was evaluated and monitored timely over a year. The overall treatment efficiency performance of the wetland system was determined by considering organic pollutants removal efficiency. This study emphasized on the design of horizontal flow constructed wetland for the effective treatment of municipal wastewater of village Majeed Keerio, Sakrand, Sindh. The constructed wetland efficiently reduced COD, BOD 5 , TSS, turbidity, total phosphate, total nitrogen pollutants of wastewater, which was about $92.3 \%, 93 \%, 96 \%, 96.4 \%$ and $74 \%$, respectively. This method reduced all thermotolerant coliforms. Constructed wetland system was found most economical and effective for the treatment of domestic wastewater. The effect of different hydraulic loading rates under varying hydraulic retention times within the constructed wetland was examined. The higher hydraulic retention times resulted in improved pollutants removal efficiency.
\end{abstract}

Keywords: Wastewater, Constructed wetland, Pollutants, Chemical oxygen demand.

\section{Introduction}

The access to clean water has become one of the most pervasive problems affecting agriculture and human health. Insufficient access to pristine water is likely to grow in upcoming years [1]. As per the report of the world health organization, more than one-tenth of the global population rely on substandard drinking water sources [2]. However, in many developing countries treatment of sewage is considered wastage of resources and therefore the least concentration is given for the development of wastewater treatment facilities [3]. Constructed wetlands are designed and constructed in such a way that it uses the natural functions of soil media, vegetation and microorganisms in a more organized atmosphere. Constructed wetlands are generally classified into three main categories such as free water surface flow constructed wetlands, subsurface flow constructed wetlands and hybrid systems depending on the inlet wastewater flow patterns and the type of macrophyte growth [4]. The application of an engineered wetland system offers easy operation and maintenance, low operational cost, high pollutant removal efficiency, sufficient potential for nutrient and water reuse. A constructed wetland is significant habitat for wildlife and is significant for sustainable wastewater management option for tropical and subtropical developing countries [5]. 
Mostly the constructed wetlands were designed and constructed for the treatment of municipal and domestic wastewater [6], but nowadays the application of these wastewater treatment systems are extended to industrial wastewaters treatment [7, 8] hospital wastewater purification [9], lake water treatment [10], stormwater runoff treatment [11], sludge treatment [12], winery waste treatment [13] and agricultural wastewater treatment [14]. Furthermore, the study regarding micropollutant removal from pharmaceutical and personal care products in tropical climates was recently reported in the literature [15]. The pollutant removal efficiencies in constructed wetlands change considerably from system to system and within the same system. The variation in performance is due to the complex combination of physical, biological and chemical processes taking place due to the soil matrix, plants, and microorganisms and their behavior with each other available in constructed wetlands [16]. A number of variables are taken into consideration during the performance analysis of the wetlands including a quantity of wastewater entering into the wetland, hydraulic retention time, type of vegetation, mode of operation and organic loading rate [17].

Most of the developing countries have warm tropical and subtropical climates, therefore the application of constructed wetland in the treatment of wastewater is very effective in such regions. Normally wetland treatment systems work well under tropical regions than in temperature regions [18]. With the increase in temperature the rates of almost all biological processes increase. A warm climate favors plant growth and enhances bacteriological activities posing a positive effect on wastewater treatment efficiency [15]. Hence tropical environments always favor the biodegradation of organic matter as well as nitrification and denitrification processes [19]. Microorganisms living in the constructed wetlands attain their maximum activity in the temperature range from $15-25^{\circ} \mathrm{C}$. While as reported by [20], the optimum temperature for nitrification in pure cultures is from $25-35^{\circ} \mathrm{C}$. In this study, the performance analysis of constructed wetland at Majeed Keerio province Sindh was performed in order to understand the fate of the pollutants entering into the constructed wetland for treatment.
The first objective of this study was to analyze the inlet and outlet pollutants such as BOD, COD, dissolved oxygen, Fecal coliform, TSS, nitrogen and phosphate for raw and treated wastewater. Whereas in a second step the outlet results were compared with the national environmental quality standard (NEQS) of Pakistan in order to assess the suitability of treated water for agriculture and aquaculture purposes.

In the year 2009-10, a small NGO Sindhica Reforms Society (Sindhica) introduced "Pakistan's first community-managed Constructed Wetland". This project was supported by Indus for All Programme and WWF Pakistan whereas the technical support was provided by UN-HABITAT Water for Asian Cities Programme, South Asia region.

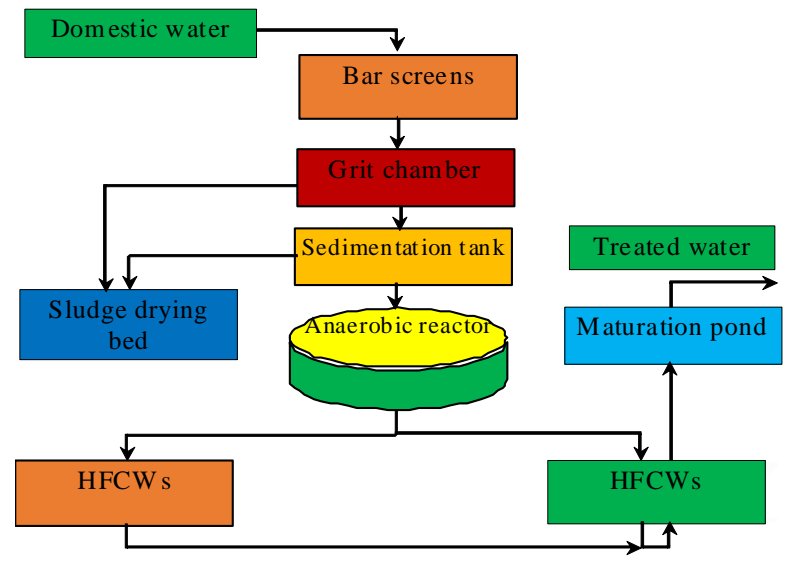

\section{Materials and Methods}

The wastewater treatment facility horizontal flow constructed wetland (HFCW) was established in 2010 located in village Majeed Keerio, District Shaheed Benazir Abad, Sindh province Pakistan $\left(26^{\circ} 15^{\prime} 0^{\prime \prime}\right.$ North $68^{\circ} 25^{\prime} 25^{\prime \prime}$ East). In summer, the climate of District Shaheed Benazir Abad is extremely hot, a temperature approaching at $50^{\circ} \mathrm{C}\left(122^{\circ} \mathrm{F}\right)$ and cold temperature drops at $4^{\circ} \mathrm{C}$ $\left(39^{\circ} \mathrm{F}\right)$ during the winters sometimes temperature falls $0^{\circ} \mathrm{C}\left(32^{\circ} \mathrm{F}\right)$. The average precipitation $\mathrm{mm}$ (inches) in the region was recorded 0.26. The population of village Majeed Keerio is around 6,000 and is situated in the bustling town of Shaheed Benazir Abad. Wastewater generated overflowed and stagnated in the streets due to nonfunctional drainage network. The domestic 
wastewater was resulting in erosion and the fertility of local farmlands was affected.

The inward flowing wastewater samples were collected from the inlet point of a constructed wetland before bar screens whereas outward flowing samples were collected at the outlet point of the maturation pond. Fig. 1 represents the flow diagram of the wetland facility developed at village Majeed Keerio. All the samples from the inlet and outlet points of the facility were taken on a fortnightly basis excluding the samples collected for Biochemical oxygen demand (BOD) $)_{5}$ and Chemical oxygen demand (COD) samples which were collected on a monthly basis.

\section{Design of CW majeed keerio}

The major designing parameters concerning constructed wetland Majeed Keerio are discussed in the below section.

\section{Municipal wastewater flow pattern}

Constructed wetland Majeed Keerio was designed as a horizontal subsurface flow pattern for domestic wastewater originating from the village.

\section{Bar screens}

Bar screens are a preliminary level of filtration during the treatment of wastewater. These are mechanical devices used for removing large objects available in influent water including plastics, rags and bottles etc. Mostly two types of bar screens are applied for filtration purpose coarse bar screens and fine bar screens. The space openings of coarse bar screens used in constructed wetland Majeed Keerio were of $8 \mathrm{~mm}$ while the fine screens used were having space opening of 1.7 mm.

\section{Septic tank}

During preliminary treatment of wastewater, a chamber made of concrete is used commonly known as a septic tank through which wastewater passes and impurities are removed. Similarly, a septic tank made of concrete were developed in constructed wetland Majeed Keerio for the preliminary treatment of domestic wastewater. The septic tank constructed was designed as a two-compartment septic tank due to its increased pollutant removal efficiency as compared to single compartment septic tank. The solids available in inlet water are removed in a septic tank. These solids if not removed from wastewater results in clogging of filter beds used for the treatment of wastewater. For the proper working of the unit, the gathered solids in septic are removed from the chamber.

\section{Anaerobic reactor}

The anaerobic reactor is a tank in which oxygen supply is restricted and the reactions involved are performed in absence of oxygen. The anaerobic reactor is developed at constructed wetland Majeed Keerio that consists upon anaerobic reactor tank and two anaerobic filter tanks in order to increase the pollutant degradation efficiency of a reactor. The baffles are provided in the reactor tank in order to increase the contact time between influent water and the biomass available in the sludge. The contact time increases as water flows under and over the baffles inserted in the anaerobic reactor at the constructed wetland Majeed Keerio.

\section{Filter beds}

Subsurface horizontal flow filter bed are constructed at village Majeed Keerio. These filter beds are aerobic in nature and filled with different sizes of rounded gravel. The constructed beds are planted with Phragmites australis plant as it can survive in saturated conditions of soil and gravel. The municipal water generated from vicinity flows in filter beds. The depth of influent water in filter beds is controlled through providing a number of inlet and outlets points in filter beds.

\section{Development of basin}

Basin construction of $\mathrm{CW}$ included earthwork in excavation, leveling and compaction. To avoid the damaging of the liner, the compaction of soil and gravel was done before the placing of the liner. During the construction of basin, the depth in the basin is designed keeping in view the maximum depth of macrophyte root. As most commonly used reed is Phragmites australis, the 
design depth of basin is normally kept 0.6 to $0.8 \mathrm{~m}$. Therefore the depth of basin was kept $0.8 \mathrm{~m}$ at constructed wetland Majeed Keerio. The slope of the basin was $1 \%$ in the flow direction.

\section{Plastic liner}

The plastic liner used for the sealing of the bed of $0.25 \mathrm{~mm}$ was placed to avoid direct interaction between the municipal water and groundwater. The leveling and compaction of ground were done before liner placing for proper installation of the liner. The liner was protected with 3 inch reinforced cement concrete (RCC) in order to avoid the damaging of liner due to sharpedged filtration media.

\section{Arrangement of inlet and outlet water in filter beds}

For proper distribution of inlet water within the filter beds number of different inlet and outlet points are provided. These inlet and outlet systems help in avoiding dead zones within the subsurface horizontal flow filter beds. The depth of water necessary for proper treatment of influent water is maintained through multiple inlet and outlet points. The distance between multiple inlets and outlet points were two feet apart from each other and thirty inlet and outlet points were arranged in each filter bed.

\section{Gravel filling}

Gravel media facilitates the growth of macrophyte, offer sustainable filtration and provides high hydraulic conductivity. The substrate used was gravel and sand. The gravel was washed with water before its placing in subsurface horizontal flow filter beds in order to remove attached solids and fine particles that could impede the filtration process within the cells. The size of gravel used for the filling was $8 / 16 \mathrm{~mm}$ gravel as it provides better growth of macrophyte and increases the treatment efficiency of a constructed wetland.

\section{Vegetation}

After construction of subsurface horizontal flow filter beds, these filter beds are planted with different types of vegetation species. Plantation of different vegetation provides eye-catching for visitors. As vegetation in filter beds helps in reduction of phosphates and nitrates available in influent water. In a constructed wetland, Majeed Keerio Phragmites australis was planted as it offers sufficient surface required for the attachment of microorganisms and controls soil erosion within the filter beds. The application of Phragmites australis in filter beds offers dual advantages over other vegetation as its growth within the filter beds is rapid and has the potential to survive in varying climatic conditions.

\section{Sludge drying bed}

A sludge drying bed was developed at the constructed wetland Majeed Keerio. The sludge is removed from the septic tank and treated for a further application for different purposes. As sludge collected from different treatment steps contains organic solids and minerals. After sludge removal from various steps it is dewatered through the sludge drying bed, moisture is removed through draining of water, evaporation and different sludge treatment steps.

\section{Physiochemical analysis}

The samples from the inlet and outlet sampling points were collected in pre-cleaned 1000 $\mathrm{mL}$ plastic bottles. All the samples collected from inlet points (raw samples) and outlet points (treated samples) were analyzed. The physiochemical investigation included $\mathrm{pH}, \mathrm{BOD}_{5}$, total suspended solids (TSS), COD, total Kjeldahl nitrogen (TKN), total phosphate (TP) whereas the biological parameters investigated include, fecal coliform and total coliform. For the analysis of $\mathrm{pH}$, Gen $\mathrm{pH}$ meter 3510 was used. Temperature, $\mathrm{pH}$, and dissolved oxygen (DO) were checked at in situ. Spectrophotometer, Lovibond spectro direct were used for the measurement of COD and TP in the inlet and outlet samples. The TKN analysis Gerhardt Digestion and Distillation apparatus, Vapodest 10sn was used. All analysis was performed as per standard methods for the examination of water and wastewater American Public Health Association (APHA, 1998). The obtained results were compared with the national 
environmental quality standards (NEQS), Pakistan for the disposal and usage of industrial and municipal wastewater as shown in Table 1 . Pollutants removal efficiencies were calculated as the percent change in concentration from the inward flowing water to outward flowing water with the help of equation (1). While mass loading rate (MLR) and mass removal rate (MRR) in $\mathrm{gP} / \mathrm{m}^{2} /$ day $(\mathrm{P}=$ concentration of pollutants) for $\mathrm{BOD}_{5}$, and total suspended solids (TSS) and in a number of $\mathrm{CU} / \mathrm{m}^{2} /$ day (CU=coliform units) for $\mathrm{FC}$ and TC were calculated using Eqs. (2) and (3), respectively [21,22].

Removal efficiency $(\mathrm{RE})=\frac{\mathrm{C}_{\mathrm{i}}-\mathrm{C}_{\mathrm{o}}}{\mathrm{C}_{\mathrm{i}}} \times 100 \%$

Mass loading rate $=\mathrm{C}_{\mathrm{i}} \times$ HLR

Mass loading rate $=\mathrm{C}_{\mathrm{i}}-\mathrm{C}_{\mathrm{o}} \times \mathrm{HLR}$

Here $\mathrm{Ci}$ represents the concentration of wastewater parameter in influent.

Whereas $\mathrm{C}_{\mathrm{o}}$ shows concentration parameter in the effluent.

Table 1. Statistical data of NEQS for municipal and industrial wastewater.

\begin{tabular}{|c|c|c|c|c|}
\hline Parameter & $\begin{array}{c}\text { Existing } \\
\text { standards }\end{array}$ & $\begin{array}{c}\text { Into } \\
\text { sewage } \\
\text { treatment }\end{array}$ & $\begin{array}{l}\text { Into land } \\
\text { water }\end{array}$ & $\begin{array}{c}\text { Into sea } \\
\text { water }\end{array}$ \\
\hline Temperature & $40^{\circ} \mathrm{C}$ & $\leq 3{ }^{\circ} \mathrm{C}$ & $\leq 3^{\circ} \mathrm{C}$ & $\leq 3^{\circ} \mathrm{C}$ \\
\hline $\mathrm{pH}$ & $6-10$ & $6-9$ & $6-9$ & $6-9$ \\
\hline COD & 150 & 400 & 150 & 400 \\
\hline $\mathrm{BOD}_{5}$ & 80 & 250 & 80 & $80 * *$ \\
\hline TSS & 150 & 400 & 200 & 400 \\
\hline Oil and grease & 10 & 10 & 10 & 10 \\
\hline TDS & 3500 & & 3500 & 3500 \\
\hline Phenolic compounds & 0.1 & 0.3 & 0.1 & 0.3 \\
\hline Chloride (as $\mathrm{cl}^{-}$) & 1000 & 1000 & 1000 & $\mathrm{SC} * * *$ \\
\hline Fluoride as $\left(\mathrm{F}^{-}\right)$ & 20 & 10 & 10 & 10 \\
\hline Cyanide (as $\mathrm{CN}^{-}$) & 2 & 1 & 1 & 1.0 \\
\hline An-ionic detergents & 20 & 20 & 20 & 20 \\
\hline Sulphate $\left(\mathrm{SO}_{4}{ }^{2-}\right)$ & 600 & 1000 & 600 & $\mathrm{SC} * * *$ \\
\hline Sulphide $\left(\mathrm{S}^{2-}\right)$ & 1 & 1 & 1 & 1 \\
\hline Ammonia $\left(\mathrm{NH}_{3}\right)$ & 40 & 40 & 40 & 40 \\
\hline Pesticides & 0.15 & 0.15 & 0.15 & 0.15 \\
\hline Cadmium & 0.1 & 0.1 & 0.1 & 0.1 \\
\hline Chromium & 1 & 1 & 1 & 1.0 \\
\hline Copper & 1 & 1 & 1 & 1 \\
\hline Lead & 0.5 & 0.5 & 0.5 & 0.5 \\
\hline
\end{tabular}

\section{Results and Discussion \\ Reduction in organic matter}

The influent and effluent values for COD and $\mathrm{BOD}_{5}$ and their percent removal rates are shown in Fig. 2 and Fig. 3, respectively. The maximum reduction in $\mathrm{BOD}_{5}$ was observed in the month of December $95.55 \pm 2.43 \%$ and the minimum reduction was noticed in March $88.11 \pm$ $2.31 \%$. The maximum reduction in COD was in November $94.11 \pm 2.61 \%$ and minimum reduction happened in the month of June $86.67 \pm 1.96 \%$ respectively. The average abatement in $\mathrm{BOD}_{5}$ was $91.82 \pm 2.11 \%$ whereas average abatement in COD was $90.34 \pm 3.66 \%$. The overall abatement in all effluent samples was well under the legal NEQS for municipal and industrial wastewaters. Thus, the reclaimed wastewater can be reused for the aquaculture and agricultural purposes. The gathered results represented that the wastewater reclaimed with the application of constructed wetland does not present major problems regarding reduction in organic matter under tropical climate conditions of the country. On the contrary, the aerated influent did not affect a reduction in organic matter efficiencies as reported by Rossman et al. [23]. Their study was done on HFCW feed with coffee processing wastewater. The hydraulic loading rate (HLR) of 7.9 days used in this study provided sufficient time for the bacterial community and their enzymes together for the reduction in both parameters.

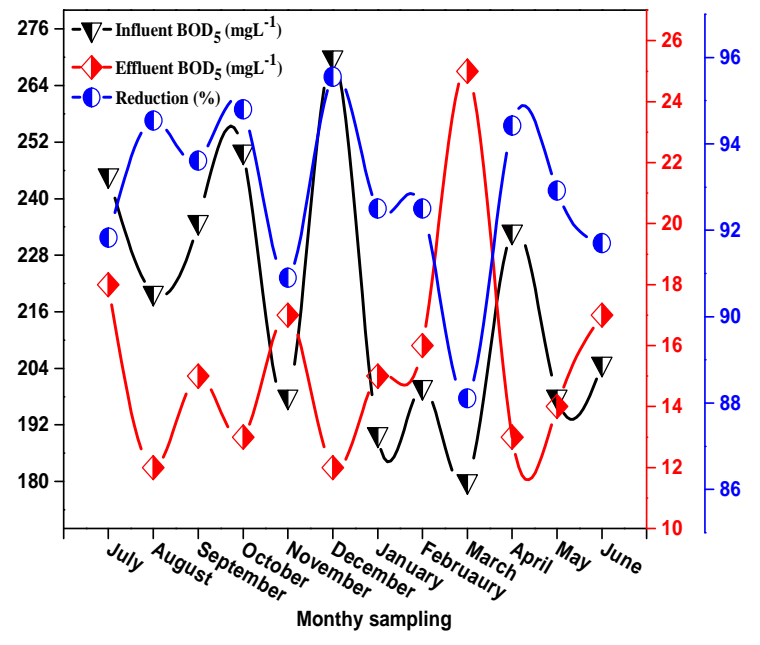

Figure 2. Biological Oxygen Demand $\left(\mathrm{BOD}_{5}\right)$ removal efficiency 


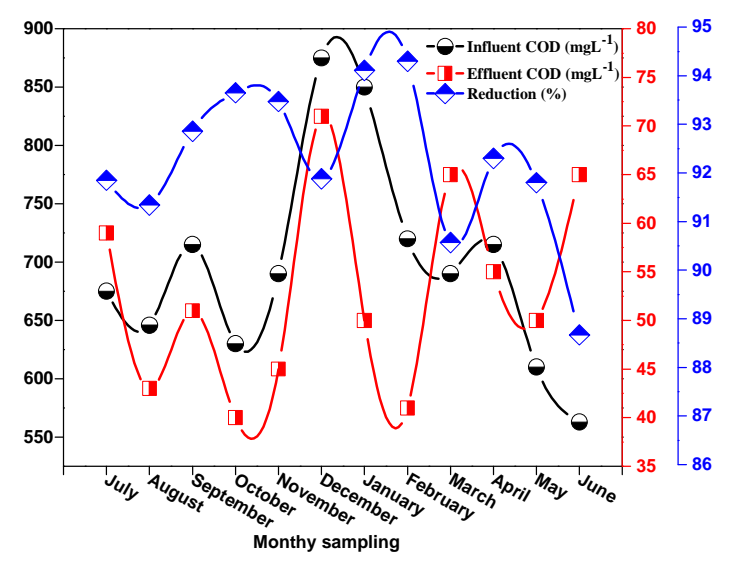

Figure 3. Chemical oxygen demand (COD) removal efficiency

\section{Reduction in total suspended solids and turbidity}

The concentration of TSS and turbidity in inward flowing water and outward flowing water from a constructed wetland are shown in Fig. 4 and 5 , respectively. The maximum particulate removal efficiency of total suspended solids $97.77 \pm 1.11 \%$ in February the minimum concentration removal was observed $95.22 \pm 2.36 \%$ in July, whereas the average concentration removal of TSS was found $96.321 \pm 1.111 \%$, respectively. The maximum reduction in turbidity as shown in Fig. 5 was achieved $97.63 \pm 2.113 \%$ in October and minimum reduction in turbidity was found in August $95.55 \pm$ $1.66 \%$, while the average turbidity abatement was noticed $96.38 \pm 2.33 \%$. However, both TSS and turbidity values are well within the NEQS for municipal and industrial wastewater and did prevent the reclaimed wastewater reuse. The reduction in TSS and turbidity parameters mostly takes place in HFCW due to the physical mechanisms such as sedimentation and filtration. These physical mechanisms involved in sedimentation and filtration processes become more effective with an increase in hydraulic retention time (HRT). Substrate and macrophyte roots promote the sedimentation and filtration processes more effectively at reduced water speed and attained high percentage removal efficiency (> $91 \%$ ), as shown in this study and those represented by different authors $[11,24]$. The results collected in this study showed that there was a complete reduction in TSS in most of the samples during the study period. In different studies, it has been reported that most of the TSS are retained within the first several meters along the bed, because of the calm conditions and superficial depth of the flow in the constructed wetland [25].

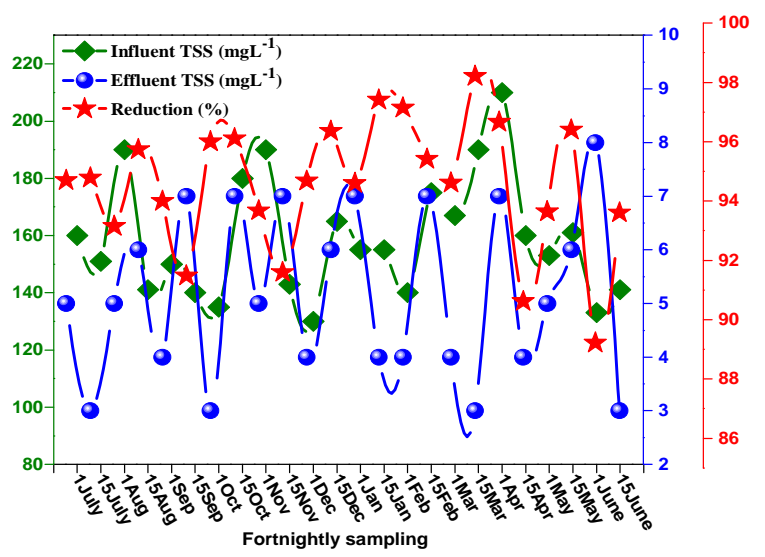

Figure 4. Total Suspended Solids (TSS) removal efficiency

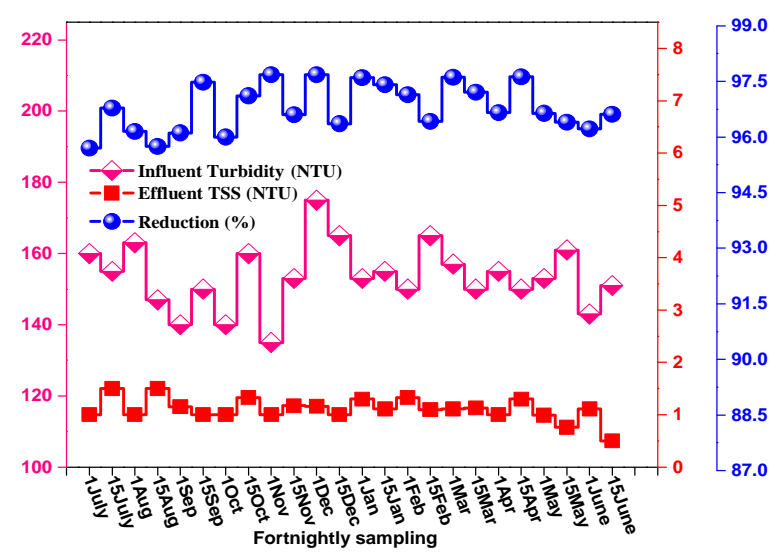

Figure 5. Turbidity removal efficiency

\section{Total nitrogen removal percentage}

Total nitrogen values observed in inward flowing water and outward flowing water from the constructed wetland are shown in Fig. 6. The maximum reduction in total nitrogen values was in December at $78.44 \% \pm 1.67$ and the minimum reduction was observed in June $68.69 \% \pm 2.13$ while the average reduction in total nitrogen was achieved at $73.44 \%$, respectively. The variations in total nitrogen values were observed in different seasons because $P$. australis is a perennial macrophyte usually showing a distinct seasonal cycle [26]. Various authors have also addressed this effect [27]. Furthermore, P. australis facilitate oxygen to the horizontal flow constructed wetland bed resulting in more active and diverse biofilm growth near the rhizosphere and enhancing the 
aerobic/ anaerobic atmospheres for total nitrogen abatement [28]. As plants perform a vital role in nitrogen reduction besides that microorganism responsible for nitrogen reduction optimally perform at a temperature above $15^{\circ} \mathrm{C}$ [26]. However, the temperature observed throughout this study period was well above $15^{\circ} \mathrm{C}$ except in January $13.5^{\circ} \mathrm{C}$. Hence in winter, the microbial activity may be affected when the temperature falls below $15^{\circ} \mathrm{C}$. While the reactions taking place in total nitrogen abatement take place more effectively in $\mathrm{pH}$ ranging from 6.5 to 8.5 [26], such as ammonification reactions require a $\mathrm{pH}$ in between 6.5 to 8.5. However, all the samples collected in this study represented a $\mathrm{pH}$ value greater than $6.5 \pm 0.3$. Additionally, the average inward flowing carbon/nitrogen of 6.7 (> 5.4) provided sufficient organic carbon source for carrying out denitrification process $[29,30]$. In the denitrification process aerated inward flows, plants and extended hydraulic retention time are effective in total nitrogen reduction. Aerated influent and large retention time provide alternate aerobic and anaerobic atmosphere and also sufficient wastewater HFCW bed contact for the concurrently going on nitrification and denitrification processes as reported by Earlier [28].

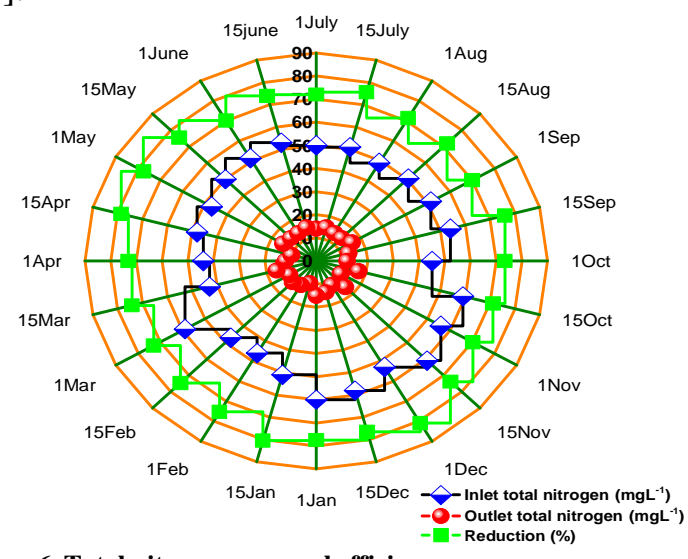

Figure 6. Total nitrogen removal efficiency

\section{Total phosphorous removal percentage}

Total phosphorous removal trend in horizontal flow constructed wetland is given in Fig. 7. The maximum reduction in TP was achieved $78.66 \pm 2.34 \%$ in July, whereas the minimum concentration removal was achieved in June $69.66 \pm 2.63 \%$. The average removal rate of
TP was $74.26 \pm 2.99 \%$, respectively. The reduction in TP takes place through the chemical and biological mechanisms, chemical mechanisms include (absorption, formation with $\mathrm{Mg}$ and $\mathrm{Ca}$ ions, precipitation with $\mathrm{Ca}, \mathrm{Al}$ and $\mathrm{Fe}$ ion), while TP reduction through biological mechanisms is due to the plant and microbial assimilation. Aeration of influents provides favorable conditions for the growth of microorganisms responsible for phosphorous immobilization [28]. However, the study carried out by Vohla et al. [31] showed that the optimal $\mathrm{pH}$ for better TP removal was $7.6 \pm$ 0.20. Furthermore Rossmann et al. [28] achieved an average TP reduction $72.1 \pm 9.5 \%$ in horizontal flow constructed wetland operated with aerated inflowing wastewater having an HRT of twelve days. Another study was done by Zorita et al. [32], on both vertical flow constructed wetlands and horizontal flow constructed wetland reported TP removal efficiency $50 \%$ and $44 \%$, operated under different planted species. Furthermore, constructed wetlands planted with different plant species effectively remove $\mathrm{PO}_{4}$ as it is freely accessible for plant uptake. As $30 \%$ of the incoming phosphate was in an organic form that may be used by the plant species only enzymatic activities could breakdown organic phosphates into inorganic form [33]. The removal of phosphates is primarily done through ligand exchange reactions in such reactions phosphate displaces hydroxyls from the surface of hydrous oxides [25]. Removal of phosphates using different plant species in constructed wetlands is visible and measurable and has been known as significant phosphate abatement method. Besides, that vegetation provides a suitable environment for microbial growth and activities [34].

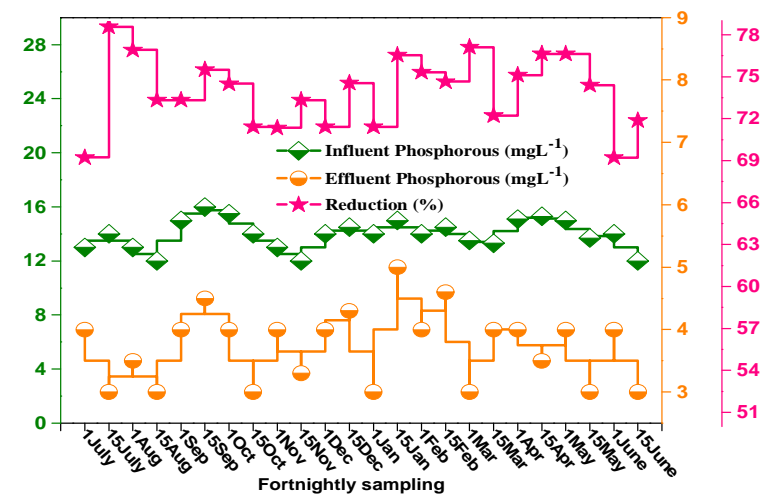

Figure 7. Total phosphorous removal efficiency 


\section{Microbial removal efficiency}

Thermotolerant coliforms and Escherichia coli values at the inlet and outlet along with their removal efficiencies are shown in Fig. 8. The maximum reduction in thermotolerant coliform counts depicted mean values in the inward flowing a wastewater and outward flowing water of $6.30 \pm$ 0.2 and $2.8 \pm 0.2 \log 10 \mathrm{CFU} / 100 \mathrm{~mL}$ respectively. The average removal of thermotolerant coliform counts was observed at $3.3 \pm 0.2 \log 10 \mathrm{CFU} / 100$ $\mathrm{mL}$. The results gathered in this study suggest that horizontal flow constructed wetlands are capable to reduce pathogenic microorganisms at a significant level. Whereas the mean value for Escherichia coli was noticed $4.9 \pm 0.2 \log 10 \mathrm{CFU} / 100 \mathrm{~mL}$ in inward flowing water and the outward flowing water was free from Escherichia coli throughout the sampling period. There are not many systems available that accomplish a complete reduction in Escherichia coli without the application of external chemical dosing or without application of external disinfectants such as ultraviolet light (UV) [35]. Moreover, efficiency in Escherichia coli removal of $5 \log 10 \mathrm{CFU} / 100 \mathrm{~mL}$ was achieved by Baeder-Bederski et al. [36] in a hybrid system (combination of horizontal flow constructed wetland followed by vertical flow constructed wetland). In another study done by Avila et al. [11], stated the same efficiency regarding Escherichia coli reduction using different hybrid system arrangements as mentioned above. The results collected in this study are very close to the results collected by various researchers as aforementioned. Fig. 8 shows the microbial removal efficiency of constructed wetland.

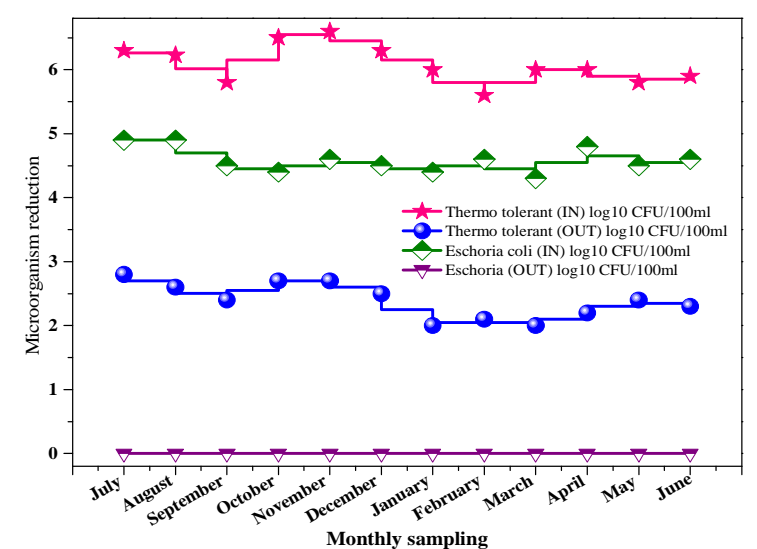

Figure 8. Microorganism removal efficiency

\section{Behavior of hydraulic loading rate}

The results gathered through influent and effluent wastewater samples on fortnightly basis at varying HLR and at varying HRT are summarized in Table 1. The HLR of $3 \mathrm{~m}^{3} /$ day produced better pollutant removal efficiencies when compared with a HLR of $6 \mathrm{~m}^{3} /$ day, $9 \mathrm{~m}^{3} /$ day and $12 \mathrm{~m}^{3} /$ day. The maximum reduction in all pollutants was found at a HLR of $3 \mathrm{~m}^{3} /$ day. Whereas the minimum reduction in pollutants was found at a hydraulic loading rate of $12 \mathrm{~m}^{3} /$ day with a corresponding HRT of 7.4 days. When HRT was reduced from 7.4 to 4.4 day the pollutants removal efficiency was decreased in all case of all selected HLR. Therefore, from experimental investigations, it was found that varying HLR pose a significant effect on the overall performance of the constructed wetland.

Table 1. Behavior of HLR with treatment efficiency.

\begin{tabular}{|c|c|c|c|c|c|c|c|c|c|c|c|c|}
\hline \multirow{2}{*}{$\begin{array}{l}\text { Parameters } \\
\text { Influent }\end{array}$} & \multicolumn{2}{|c|}{$\mathrm{BOD}_{5} \mathrm{mg} / \mathrm{L}$} & \multicolumn{2}{|c|}{ COD mg/L } & \multicolumn{2}{|c|}{ TSS mg/L } & \multicolumn{2}{|c|}{ Phosphorous mg/L } & \multicolumn{2}{|c|}{ Nitrogen $\mathrm{mg} / \mathrm{L}$} & \multicolumn{2}{|c|}{ Turbidity NTU } \\
\hline & value & RR \% & Value & RR \% & Value & RR \% & Value & RR \% & Value & RR \% & Value & RR \% \\
\hline $3 \mathrm{~m}^{3} /$ day & 111 & 89 & 383 & 90 & 74 & 93 & 15 & 73 & 45 & 68 & 99 & 98 \\
\hline $6 \mathrm{~m}^{3} /$ daym $^{2}$ & 132 & 75 & 410 & 82 & 80 & 91 & 19 & 66 & 51 & 55 & 110 & 97 \\
\hline $9 \mathrm{~m}^{3} / \mathrm{daym}^{2}$ & 144 & 69 & 444 & 78 & 101 & 88 & 23 & 55 & 52 & 49 & 115 & 95 \\
\hline $12 \mathrm{~m}^{3} / \mathrm{daym}^{2}$ & 165 & 51 & 491 & 65 & 120 & 74 & 28 & 43 & 60 & 39 & 140 & 93 \\
\hline
\end{tabular}




\section{Conclusion}

Municipal wastewater is being produced from domestic use and is being disposed-off into rivers without any treatment, which pollutes fresh water as well. The physicochemical parameters of wastewater/treated wastewater such as COD, $\mathrm{BOD}_{5}$, TSS, turbidity, $\mathrm{pH}$ and nitrogen were analyzed. This system efficiently reduced COD, $\mathrm{BOD}_{5}$, TSS, turbidity, total phosphate, nitrogen pollutants $92.3 \%, 93 \%$, and $96 \%, 96.4 \%$ and $74 \%$ respectively. The pollutants reduction rate increased with increasing retention time of wastewater within the treatment facility. At a HLR of $3 \mathrm{~m}^{3} /$ day and HRT of 7.4 days, maximum pollutants removal efficiency was noticed. The maximum pollutant removal efficiency at $3 \mathrm{~m}^{3} /$ day and HRT of 7.4 days the reduction percent in $\mathrm{BOD}_{5}$ was $89 \%$, COD $90 \%$, TSS 93\%, Phosphorous $73 \%$, Nitrogen $68 \%$ and turbidity $98 \%$ during the study period. The maximum reduction in thermotolerant coliform counts depicted mean values in the inward flowing a wastewater and outward flowing water of $6.30 \pm$ 0.2 and $2.8 \pm 0.2 \log 10 \mathrm{CFU} / 100 \mathrm{~mL}$ respectively. The average removal of thermotolerant coliform counts was observed at $3.3 \pm 0.2 \log 10 \mathrm{CFU} / 100$ $\mathrm{mL}$. Whereas the mean value for Escherichia coli was noticed $4.9 \pm 0.2 \log 10 \mathrm{CFU} / 100 \mathrm{ml}$ in inward flowing water and the outward flowing water was free from Escherichia coli throughout the sampling period. The statistical results gathered in this study regarding $\mathrm{BOD}_{5}, \mathrm{COD}$, TSS, turbidity, phosphorus, nitrogen, fecal coliform reduction rates and the effect of different HLR under varying HRT could be used for the designing of constructed wetland for refinement of municipal wastewater in different areas of the country.

\section{Acknowledgment}

The authors are thankful to worldwide fund for nature (WWF-Pakistan) for the financial support provided to undertake this study.

\section{References}

1. M. A. Shannon, P. W. Bohn, M. Elimelech, J. G. Georgiadis, B. J. Mariñas and A. M. Mayes, Nature, 452 (2009) 301. doi:10.1038/nature06599
2. Progress on Sanitation and Drinking-Water: 2012 Update. WHO and UNICEF; Geneva, Swizerland and New York, NY (2012)

3. D. Konnerup, N. T. D. Trang and H. Brix, Aquaculture, 313 (2011) 57.

doi:10.1016/j.aquaculture.2010.12.026

4. J. Vymazal, Sci. Total Environ., 380 (2007) 48.

doi:10.1016/j.scitotenv.2006.09.014

5. U. Stottmeister, A. Wiebner, P. Kuschk, U. Kappelmeyer, M. Kästner, O. Bederski, R. A. Müller and H. Moormann, Biotechnol. Adv., 22 (2003) 93.

doi:10.1016/j.biotechadv.2003.08.010

6. K. B. S. N. Jinadasa, N. Tanaka, M. I. M. Mowjood and D. R. I. B. Werellagama, Chem. Ecol., 22 (2006) 181. doi: $\underline{10.1080 / 02757540600658849}$

7. Y. F. Lin, S. R. Jing, D. Y. Lee and T. W. Wang, Aquaculture, 209 (2002) 169. doi: $10.1016 /$ S0044-8486(01)00801-8

8. C. Y. Lee, C. C. Lee, F. Y. Lee, S. K. Tseng and C. J. Liao, Bioresour. Technol., 92 (2004) 173. doi:10.1016/j.biortech.2003.08.012

9. R. R. Shrestha, R. Haberl, J. Laber, R. Manandhar and J. Mader, Water Sci. Technol., 44 (2001) 381. doi: iwaponline.com/content/44/11-12/381

10. M. Martín, N. Oliver, C. Hernández-Crespo, S. Gargallo and M. C. Regidor, Ecol. Eng., 50 (2013) 52. doi:10.1016/j.ecoleng.2012.04.029

11. C. Ávila, j. j. Salas, I. Martín, C. Aragón and J. García, Ecol. Eng., 50 (2013) 13. doi:10.1016/j.ecoleng.2012.08.009

12. S. Kantawanichkul, S. Somprasert, U. Aekasin and R. B. E. Shutes, Water Sci. Technol., 48 (2003) 199. doi: iwaponline.com/content/48/5/199

13. L. Serrano, D. de la Varga, I. Ruiz and M. Soto, Ecol. Eng., 37 (2011) 744. doi:10.1016/j.ecoleng.2010.06.038

14. H. Lian-sheng, L. Hong-liang, X. Bei-dou and Z. Ying-bo, Water Sci. Technol., 54 (2006) 137. doi: $\underline{10.2166 / \text { wst. } 2006.845}$ 
15. D. Q. Zhang, S. K. Tan, R. M. Gersberg, S. Sadreddini, J. Zhu and N. A. Tuan, Ecol. Eng., 37 (2011) 460. doi:10.1016/j.ecoleng.2010.11.002

16. N. Trang, D. Konnerup, H. H. Schierup, N. Huu Chiem, H. Le and T. Brix, Ecol. Eng., 36 (2010) 527. doi:10.1016/i.ecoleng.2009.11.022

17. J. L. Faulwetter, V. Gagnon, C. Sundberg, F. Chazarenc, M. D. Burr, J. Brisson, A. K. Camper and O. R. Stein, Ecol. Eng., 35 (2009) 987. doi: $10.1016 /$ j.ecoleng.2008.12.030

18. A. K. Kivaisi, Ecol. Eng., 16 (2001) 545. doi:10.1016/S0925-8574(00)00113-0

19. M. Truu, J. Juhanson and J. Truu, Sci. Total Environ., 407 (2009) 3958. doi:10.1016/j.scitotenv.2008.11.036

20. J. Vymazal, Ecol. Eng., 25 (2005) 478. doi:10.1016/j.ecoleng.2005.07.010

21. J. Chang, X. H. Zhang, R. Perfler, Q. S. Xu, X. Y. Niu and Y. Ge, Fresenius Environ. Bull., 16 (2007) 1082.

doi: blse\%3arn216416026/effect-ofhydraulic-loading-rate-on-the-removal/

22. S. R. Jing, Y. F. Lin, T. W. Wang and D. Y. Lee, J. Environ. Qual., 31(2002) 690. doi: $10.2134 /$ jeq2002.6900

23. M. Rossmann, A. T. Matos, E. C. Abreu, F. F. Silva and A. C. Borges, J. Environ. Manage., 128 (2013) 912. doi:10.1016/j.jenvman.2013.06.045

24. P. Andreo-Martínez, N. García-Martínez and L. Almela, Water, 8 (2016) 434. doi: $10.3390 /$ w8100434

25. J. Vymazal and M. Masa, Water Sci. Technol., 48 (2003) 143. doi: iwaponline.com/content/48/5/143.

26. T. Saeed and G. Sun, J. Environ. Manage., 112 (2012) 429. doi:10.1016/j.jenvman.2012.08.011
27. C. S. Akratos and V. A. Tsihrintzis, Ecol. Eng., 29 (2007)173. doi:10.1016/j.ecoleng.2006.06.013

28. M. Rossmann, A. T. Matos, E. C. Abreu, F. F. e Silv and A. C. Borges, Ecol. Eng., 49 (2012) 264. doi:10.1016/j.ecoleng.2012.08.017

29. Y. He, Y. Wang and X. Song, Bioresour. Technol., 203 (2016) 245. doi:10.1016/j.biortech.2015.12.060

30. F. Li, L. Lu, X. Zheng, H. H. Ngo, S. Liang, W. Guo and X. Zhang. Bioresour. Technol., 169 (2014) 395. doi:10.1016/j.biortech.2014.07.004

31. C. Vohla, M. Kõiv, H. J. Bavor, F. Chazarenc and U. Mander, Ecol. Eng., 37 (2011) 70 . doi:10.1016/j.ecoleng.2009.08.003

32. F. Zurita, J. De Anda and M. A. Belmont, Ecol. Eng. 35 (2009) 861. doi:10.1016/j.ecoleng.2008.12.026

33. H. Kang, S. Y. Kim, N. Fenner, C. Freeman, Sci. Total Environ., 337 (2005) 207. doi:10.1016/j.scitotenv.2004.06.015

34. P. Klomjek and S. Nitisoravut, Chemosphere, 58 (2005) 585. doi:10.1016/j.chemosphere.2004.08.073

35. H. Azaizeh, K. G. Linden, C. Barstow, S. Kalbouneh, A. Tellawi, A. Albalawneh and Y. Gerchman, Water Sci. Technol., 67 (2012) 651. doi:10.2166/wst.2012.615

36. O. Baeder-Bederski, M. Durr, M. BorneffLipp, P. Kuschk, R. Netter, G. Daeschlein, P. Mosig and R. A. Muller, Water Sci. Technol., 51 (2005) 205. doi:iwaponline.com/content/51/9/205 